\title{
Malnutrition and health in developing countries
}

\author{
Olaf Müller, Michael Krawinkel
}

\section{Abstract}

MALNUTRITION, WITH ITS 2 CONSTITUENTS of protein-energy malnutrition and micronutrient deficiencies, continues to be a major health burden in developing countries. It is globally the most important risk factor for illness and death, with hundreds of millions of pregnant women and young children particularly affected. Apart from marasmus and kwashiorkor (the 2 forms of proteinenergy malnutrition), deficiencies in iron, iodine, vitamin $\mathrm{A}$ and zinc are the main manifestations of malnutrition in developing countries. In these communities, a high prevalence of poor diet and infectious disease regularly unites into a vicious circle. Although treatment protocols for severe malnutrition have in recent years become more efficient, most patients (especially in rural areas) have little or no access to formal health services and are never seen in such settings. Interventions to prevent proteinenergy malnutrition range from promoting breast-feeding to food supplementation schemes, whereas micronutrient deficiencies would best be addressed through food-based strategies such as dietary diversification through home gardens and small livestock. The fortification of salt with iodine has been a global success story, but other micronutrient supplementation schemes have yet to reach vulnerable populations sufficiently. To be effective, all such interventions require accompanying nutrition-education campaigns and health interventions. To achieve the hunger- and malnutrition-related Millennium Development Goals, we need to address poverty, which is clearly associated with the insecure supply of food and nutrition.

CMAJ 2005;173(3):279-86

M alnutrition continues to be a major public health problem throughout the developing world, particularly in southern Asia and sub-Saharan Africa. ${ }^{1-5}$ Diets in populations there are frequently deficient in macronutrients (protein, carbohydrates and fat, leading to protein-energy malnutrition), micronutrients (electrolytes, minerals and vitamins, leading to specific micronutrient deficiencies) or both. ${ }^{3,6-8}$

The high prevalence of bacterial and parasitic diseases in developing countries contributes greatly to malnutrition there. ${ }^{3,5,9-11}$ Similarly, malnutrition increases one's susceptibility to and severity of infections, and is thus a major comf ponent of illness and death from disease..$^{3,5,12-14}$ Malnutrition is consequently the most important risk factor for the burden of disease in developing countries. ${ }^{12,15}$ It is the direct cause of about 300000 deaths per year and is indirectly responsible for about half of all deaths in young children (Fig. 1). ${ }^{5,15-17}$ The risk of death is directly correlated with the degree of malnutrition. ${ }^{17-22}$
Poverty is the main underlying cause of malnutrition and its determinants (Fig. 2). ${ }^{23,24}$ The degree and distribution of protein-energy malnutrition and micronutrient deficiencies in a given population depends on many factors: the political and economic situation, the level of education and sanitation, the season and climate conditions, food production, cultural and religious food customs, breast-feeding habits, prevalence of infectious diseases, the existence and effectiveness of nutrition programs and the availability and quality of health services. ${ }^{3,5-7,25-27}$

Here we provide an overview on the epidemiology, pathophysiology, clinical features, management and control of protein-energy malnutrition and micronutrient deficiencies in developing countries.

\section{Protein-energy malnutrition}

\section{Epidemiology}

Worldwide, an estimated 852 million people were undernourished in 2000-2002, with most ( 815 million) living in developing countries. ${ }^{5}$ The absolute number of cases has changed little over the last decade. However,

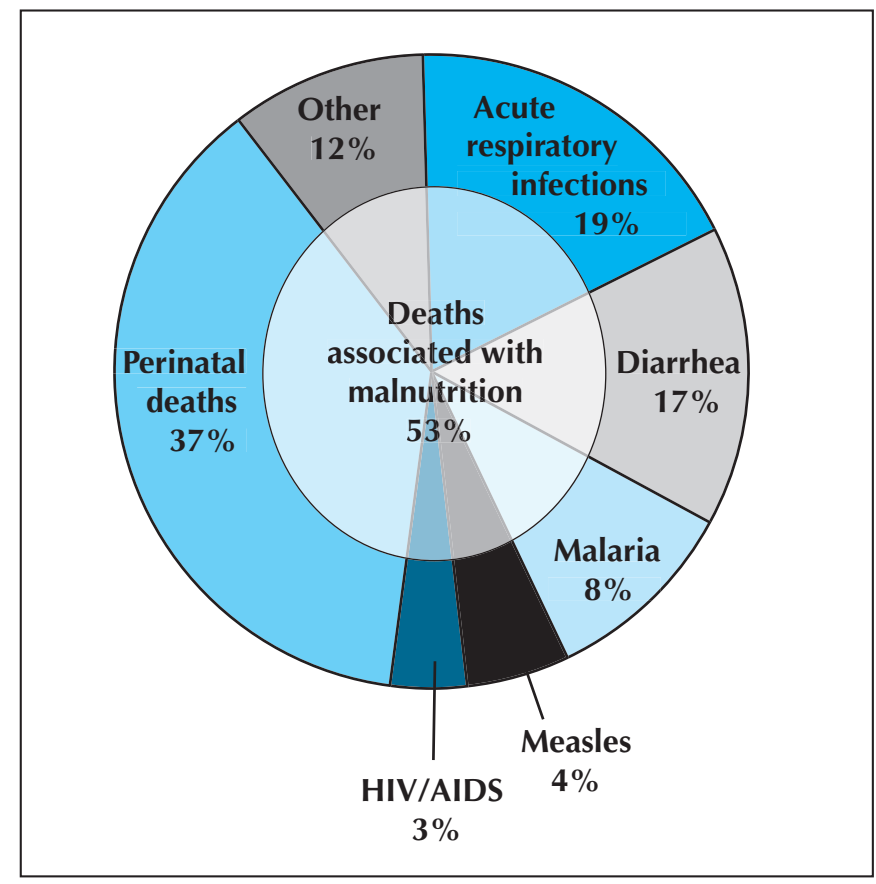

Fig. 1: Causes of death among children under 5 years of age, 2000-2003, worldwide. 
while China had major reductions in its number of cases of protein-energy malnutrition during this period, this was balanced by a corresponding increase in the rest of the developing world. ${ }^{5}$

In children, protein-energy malnutrition is defined by measurements that fall below 2 standard deviations under the normal weight for age (underweight), height for age (stunting) and weight for height (wasting). ${ }^{6}$ Wasting indicates recent weight loss, whereas stunting usually results from chronic weight loss. Of all children under the age of 5 years in developing countries, about $31 \%$ are underweight, $38 \%$ have stunted growth and $9 \%$ show wasting. ${ }^{3}$ Proteinenergy malnutrition usually manifests early, in children between 6 months and 2 years of age and is associated with early weaning, delayed introduction of complementary foods, a low-protein diet and severe or frequent infections. ${ }^{13,16,28}$ Table 1 shows the geographic distribution of protein-energy malnutrition among young children in developing countries. ${ }^{5}$

Severe malnutrition, typified by wasting, edema or both, occurs almost exclusively in children. ${ }^{3}$ Marasmus is defined as severe wasting; marasmic kwashiorkor, as severe wasting in the presence of edema; and kwashiorkor, as malnutrition with edema. ${ }^{3,29}$ The word kwashiorkor originates from the Ga language in Ghana; it implies "the disease that the

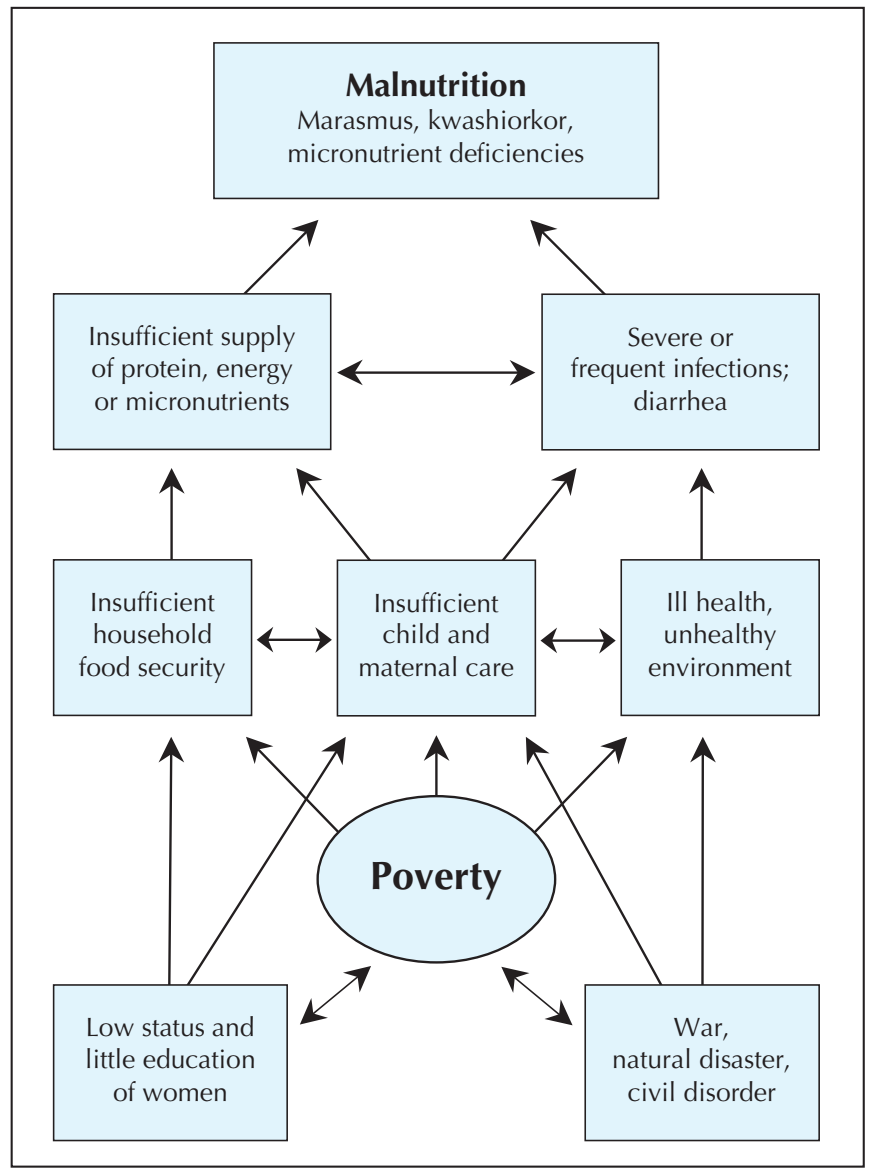

Fig. 2: Direct and indirect causes of malnutrition. young child developed when displaced from his mother by another child or pregnancy." Early marasmus, occurring in the first year of life, is frequently associated with contaminated bottle-feeding in urban areas. ${ }^{6}$

\section{Pathophysiology and clinical features}

After insufficient supply of protein, carbohydrates and fat, the next major cause of protein-energy malnutrition is severe and chronic infections - particularly those producing diarrhea, but also other diseases such as helminthic infections. The underlying mechanisms include decreased food intake because of anorexia, decreased nutrient absorption, increased metabolic requirements and direct nutrient losses. ${ }^{6,30}$

The term protein-energy malnutrition describes the cause (i.e., the imbalance between nutrient supplies and requirements) more than the pathogenesis of starvation. ${ }^{31}$ The pathologic changes include immunologic deficiency in the humoral and cellular subsystem from protein deficiency and lack of immune mediators (e.g., tumour necrosis factor). Metabolic disturbances also play a role in impaired intercellular degradation of fatty acids because of carbohydrate deficiency. Synthesis of pigments in the hair and skin fails (e.g., hair colour may change and skin become hyperpigmented) because of a lack of substrate (e.g., tyrosin) and coenzymes. ${ }^{32}$

Marasmus is diagnosed when subcutaneous fat and muscle are lost because of endogenous mobilization of all available energy and nutrients. Clinical aspects typically include a triangular face, primary or secondary amenorrhea, extended abdomen (from muscular hypotonia) and anal or rectal prolapse (from loss of perianal fat). ${ }^{33}$

Kwashiorkor usually manifests with edema, changes to hair and skin colour, anemia, hepatomegaly, lethargy, severe immune deficiency and early death. Despite decades of debate, sometimes quite intense, the pathologic features of kwashiorkor are still not fully understood. ${ }^{3}$ The role of aflatoxins and insufficient protein intake has been stressed because the presence of edema and ascites seems related to reduced osmolarity in the blood, which is thought to be caused mostly by severe anemia. ${ }^{34}$ It is puzzling that total protein concentrations in the plasma do not differ between children with marasmus and those with kwashiorkor. ${ }^{35}$

Table 1: Prevalences of protein-energy malnutrition among children under 5 years of age in developing countries, 1995

\begin{tabular}{lccc}
\hline Region & $\begin{array}{c}\text { Stunting, } \\
\%\end{array}$ & $\begin{array}{c}\text { Underweight, } \\
\%\end{array}$ & $\begin{array}{c}\text { Wasting, } \\
\%\end{array}$ \\
\hline Africa & 39 & 28 & 8 \\
Asia & 41 & 35 & 10 \\
Latin America & & 10 & 3 \\
and Caribbean & 18 & 23 & 5 \\
Oceania & 31 & & \\
\hline
\end{tabular}


More recently, a role for free radicals in the etiology of kwashiorkor has been considered, ${ }^{36-43}$ but the findings of initial intervention studies have not been up to expectations. This may possibly be the result of inappropriate experimental design..$^{44,45}$

One essential aspect of severe protein-energy malnutrition is the fatty degeneration of such diverse organs as the liver and heart. This degeneration is not just a sign of severe malnutrition; it causes subclinical or overt cardiac insufficiency, especially when malnutrition is accompanied by edema. ${ }^{46}$ If the myocardial insufficiency is not corrected, iatrogenic fluid and sodium overload quickly escalate it into cardiac failure. A second injurious aspect is the loss of subcutaneous fat, which markedly reduces the body's capacity for temperature regulation and water storage. ${ }^{4749}$ As a consequence, malnourished children become dehydrated, hypothermic and hypoglycemic more quickly and severely than others. Finally, severe protein-energy malnutrition is associated with atrophy of the mucosa of the small bowel, leading to a loss of absorption as well as of digestion capacity. ${ }^{48}$

Severe malnutrition is furthermore associated with chronic hypovolemia, which leads to secondary hyperaldosteronism, and further complicates fluid and electrolyte balance. Because the development of muscular dystrophy mobilizes much of the body's potassium, which is then lost through urinary excretion, affected children do not show signs of hyperkalemia. ${ }^{50}$

Most children with severe protein-energy malnutrition have asymptomatic infections because their immune system fails to respond with chemotaxis, opsonization and phagocytosis of bacteria, viruses or fungi. So depressed is the system that the body cannot produce even the fever that is typical of inflammation. ${ }^{33}$

Malnutrition is diagnosed by anthropometric measurements and physical examination. Where available, some laboratory investigations are helpful (Table 2).

\begin{tabular}{|c|c|}
\hline Blood or plasma variables & The information derived \\
\hline $\begin{array}{l}\text { Hemoglobin, hematocrit, } \\
\text { erythrocyte count, mean } \\
\text { corpuscular volume }\end{array}$ & $\begin{array}{l}\text { Degree of dehydration and anemia; } \\
\text { type of anemia (iron/folate and vitamin } \\
\mathrm{B}_{12} \text { deficiency, hemolysis, malaria) }\end{array}$ \\
\hline Glucose & Hypoglycemia \\
\hline $\begin{array}{l}\text { Electrolytes and alkalinity } \\
\text { Sodium } \\
\text { Potassium } \\
\text { Chloride, pH, bicarbonate }\end{array}$ & $\begin{array}{l}\text { Hyponatremia, type of dehydration } \\
\text { Hypokalemia } \\
\text { Metabolic alkalosis or acidosis }\end{array}$ \\
\hline $\begin{array}{l}\text { Total protein, transferrin, } \\
\text { (pre-)albumin }\end{array}$ & Degree of protein deficiency \\
\hline Creatinine & Renal function \\
\hline $\begin{array}{l}\text { C-reactive protein, } \\
\text { lymphocyte count, serology, } \\
\text { thick and thin blood films }\end{array}$ & $\begin{array}{l}\text { Presence of bacterial or viral infection } \\
\text { or malaria }\end{array}$ \\
\hline Stool examination & Presence of parasites \\
\hline
\end{tabular}

\section{Management and control}

Despite the manifold dietary approaches to severe malnutrition that have been tried, ${ }^{51,52}$ patients with kwashiorkor (including marasmic kwashiorkor) continue to die much more frequently than those with marasmus alone. ${ }^{1,53,54}$ In sub-Saharan Africa and, increasingly, India, an additional concern is that many patients with severe malnutrition are also infected with HIV. ${ }^{55}$

The high mortality indicates a need for a systematic approach to the severely malnourished patient that goes beyond an appropriate diet. To reduce mortality, a complex management scheme is pivotal. ${ }^{56}$ Essential steps include a reduced intake of volume, protein and sodium during the first phase while emergency measures are taken to reduce the risk of hypoglycemia, hypothermia and dehydration. ${ }^{57-59}$ Oral, enteral and parenteral volume loads must be checked carefully to avoid imminent heart failure; continous monitoring of central venous blood pressure is very desirable. In this early phase of rehabilitation, a protein intake exceeding $1 \mathrm{~g} / \mathrm{kg}$ body weight in combination with impaired liver function (with breakdown of the urea cycle) and little urine excretion (a result of dehydration) easily exceeds the malnourished child's metabolic capacity to rid him- or herself of excess ammonia.

Although the effectiveness of the World Health Organization (WHO) 10-step scheme (shown in Table 3) is proven, there are still pitfalls for certain patients, such as those with extreme anemia and those who are close to cardiac failure. ${ }^{60}$ The need for transfusions must be weighed against the risk of heart failure; combining transfusions with diuresis or applying exchange transfusion can resolve the dilemma. The WHO is currently revising its protocol to address 3 difficulties: the specific nutritional problems of

\section{Table 3: Elements in the management of severe protein- energy malnutrition ${ }^{60}$}

\begin{tabular}{|c|c|}
\hline Problem & Management \\
\hline Hypothermia & $\begin{array}{l}\text { Warm patient up; maintain and monitor body } \\
\text { temperature }\end{array}$ \\
\hline Hypoglycemia & $\begin{array}{l}\text { Monitor blood glucose; provide oral (or intra- } \\
\text { venous) glucose }\end{array}$ \\
\hline Dehydration & $\begin{array}{l}\text { Rehydrate carefully with oral solution containing } \\
\text { less sodium and more potassium than standard mix }\end{array}$ \\
\hline Micronutrients & Provide copper, zinc, iron, folate, multivitamins \\
\hline Infections & $\begin{array}{l}\text { Administer antibiotic and antimalarial therapy, even } \\
\text { in the absence of typical symptoms }\end{array}$ \\
\hline Electrolytes & Supply plenty of potassium and magnesium \\
\hline Starter nutrition & Keep protein and volume load low \\
\hline $\begin{array}{l}\text { Tissue-building } \\
\text { nutrition }\end{array}$ & $\begin{array}{l}\text { Furnish a rich diet dense in energy, protein and all } \\
\text { essential nutrients that is easy to swallow and digest }\end{array}$ \\
\hline Stimulation & $\begin{array}{l}\text { Prevent permanent psychosocial effects of } \\
\text { starvation with psychomotor stimulation }\end{array}$ \\
\hline $\begin{array}{l}\text { Prevention of } \\
\text { relapse }\end{array}$ & $\begin{array}{l}\text { Start early to identify causes of protein-energy } \\
\text { malnutrition in each case; involve the family and } \\
\text { the community in prevention }\end{array}$ \\
\hline
\end{tabular}


children with HIV infection or AIDS; different dietary regimens, particularly for infants younger than 6 months; and the limited availability of potassium-magnesium-zinccopper preparations. ${ }^{61}$

The need to reduce the high sodium content $(90 \mathrm{mEq} / \mathrm{L})$ of common oral rehydration solutions for starving children has led to the production of ReSoMal (a 45-mEq/L rehydration solution for the malnourished). Now that a 75$\mathrm{mEq} / \mathrm{L}$ oral rehydration solution has become a standard treatment for nonsecretory diarrhea, ${ }^{62,63}$ there is less need for a special sodium-reduced rehydration preparation. Nevertheless, modification of the standard oral rehydration solution is recommended, with dilution to reduce the sodium concentration and enrichment with potassium, magnesium, zinc, copper and selenium. ${ }^{48,50,64}$ Finally, the severely malnourished child should always be given an effective broad-spectrum antibiotic, even in the absence of any signs of infection. ${ }^{65,66}$

People's diets can benefit from preventive interventions ranging from income generation and nutritional education to maternal support, food supplementation and food prize subsidies. High immunization coverage and early and correct management of cases of infectious disease play major roles in the prevention and treatment of protein-energy malnutrition. ${ }^{13}$ In poor communities, the treatment of helminth infections 3 times per year improved child growth and development. ${ }^{15}$

Protein-energy malnutrition and diarrhea typically interact in a vicious cycle, but the control of diarrhea depends on more than medical help. ${ }^{30,67}$ Although growth monitoring is considered potentially important in child health clinics, there is often a lack of appropriate follow-up action. ${ }^{6,68-70}$ As much as functional health services may need to be made available, in order to address infectious diseases as a cause of protein-energy malnutrition it is likewise important to promote breast-feeding, improve the water supply and sanitation, and educate people about hygiene. ${ }^{715,71-74}$ The multifaceted horizontal approach of the WHO-supported Integrated Management of Childhood Illness initiative has recently been shown to be an effective strategy. ${ }^{75,76}$

\section{Micronutrient deficiencies}

\section{Epidemiology}

Deficiencies in iron, iodine, vitamin A and zinc are still major public health problems in developing countries, but vitamin $\mathrm{C}, \mathrm{D}$ and $\mathrm{B}$ deficiencies have declined considerably in recent decades. ${ }^{7,77}$ Micronutrient deficiencies affect at least 2 billion people worldwide. ${ }^{5}$ As there are often no reliable biochemical indices of marginal micronutrient status, randomized controlled trials of supplementation are the best method to study the relation between micronutrient deficiencies and health parameters in human populations. ${ }^{78}$

Globally, 740 million people are deficient in iodine, including up to 300 million with goitre and 20 million with brain damage from maternal iodine deficiency during their fetal development. ${ }^{7,79-81}$ About 2 billion people are deficient in zinc; 1 billion have iron-deficiency anemia. Vitamin A deficiency affects some 250 million, mainly young children and pregnant women in developing countries. ${ }^{14,82-102}$ The main causes worldwide of these 4 major micronutrient deficiencies are shown in Table 4.

\section{Pathophysiology and clinical features}

Not only do protein-energy malnutrition and micronutrient deficiencies overlap, but a lack of 1 micronutrient

\section{Table 4: Causes, manifestations, management and prevention of the major micronutrient deficiencies}

\begin{tabular}{|c|c|c|c|c|}
\hline Nutrient & $\begin{array}{l}\text { Essential for } \\
\text { the production } \\
\text { or function of }\end{array}$ & $\begin{array}{c}\text { Causes } \\
\text { of deficiency }\end{array}$ & $\begin{array}{l}\text { Manifestations of } \\
\text { isolated deficiency }\end{array}$ & $\begin{array}{l}\text { Management } \\
\text { and prevention }\end{array}$ \\
\hline Iron & $\begin{array}{l}\text { Hemoglobin } \\
\text { Various enzymes } \\
\text { Myoglobin }\end{array}$ & $\begin{array}{l}\text { Poor diet } \\
\text { Elevated needs (e.g., while pregnant, } \\
\text { in early childhood) } \\
\text { Chronic loss from parasite infections } \\
\text { (e.g., hookworms, schistosomiasis, } \\
\text { whipworm) }\end{array}$ & $\begin{array}{l}\text { Anemia and fatigue } \\
\text { Impaired cognitive development } \\
\text { Reduced growth and physical strength }\end{array}$ & $\begin{array}{l}\text { Foods richer in iron and with } \\
\text { fewer absorption inhibitors } \\
\text { Iron-fortified weaning foods } \\
\text { Low-dose supplements in } \\
\text { childhood and pregnancy } \\
\text { Cooking in iron pots }\end{array}$ \\
\hline lodine & $\begin{array}{l}\text { Thyroid } \\
\text { hormone }\end{array}$ & $\begin{array}{l}\text { Except where seafood or salt fortified } \\
\text { with iodine is readily available, most } \\
\text { diets, worldwide, are deficient }\end{array}$ & $\begin{array}{l}\text { Goitre, hypothyroidism, constipation } \\
\text { Growth retardation } \\
\text { Endemic cretinism }\end{array}$ & $\begin{array}{l}\text { lodine supplement } \\
\text { Fortified salt } \\
\text { Seafood }\end{array}$ \\
\hline $\begin{array}{l}\text { Vitamin } \\
\text { A }\end{array}$ & $\begin{array}{l}\text { Eyes } \\
\text { Immune system }\end{array}$ & $\begin{array}{l}\text { Diets poor in vegetables and animal } \\
\text { products }\end{array}$ & $\begin{array}{l}\text { Night blindness, xerophthalmia } \\
\text { Immune deficiency } \\
\text { Increased childhood illness, early death } \\
\text { Contributes to development of anemia }\end{array}$ & $\begin{array}{l}\text { More dark green leafy } \\
\text { vegetables, animal products } \\
\text { Fortification of oils and fats } \\
\text { Regular supplementation* }\end{array}$ \\
\hline Zinc & $\begin{array}{l}\text { Many enzymes } \\
\text { Immune system }\end{array}$ & $\begin{array}{l}\text { Diets poor in animal products } \\
\text { Diets based on refined cereals (e.g., } \\
\text { white bread, pasta, polished rice) }\end{array}$ & $\begin{array}{l}\text { Immune deficiency } \\
\text { Acrodermatitis } \\
\text { Increased childhood illness, early death } \\
\text { Complications in pregnancy, childbirth }\end{array}$ & $\begin{array}{l}\text { Zinc treatment for diarrhea } \\
\text { and severe malnutrition } \\
\text { Improved diet }\end{array}$ \\
\hline
\end{tabular}

*Regular vitamin A supplementation is sometimes a part of immunization programs. 
is typically associated with deficiencies of other micronutrients. The pathophysiology and manifestations of the main deficiencies are summarized in Table 4.

Iron is an essential part of hemoglobin, myoglobin and various enzymes. Its deficiency thus leads mainly to anemia, but also to several other adverse effects. ${ }^{7,15,23,83}$

Lack of iodine reduces the production of thyroid hormone and increases that of thyroid-stimulating hormone. As a result, the thyroid gland becomes hyperplastic and goitrous, and hypothyroidism develops., ${ }^{3,7}$

Vitamin A deficiency contributes to anemia by immobilizing iron in the reticuloendothelial system, reducing hemopoiesis and increasing susceptibility to infections. Vitamin A is essential for the functioning of the eyes as well as the immune system..$^{83,103}$ Although diarrhea and related mortality has clearly been shown to be associated with vitamin A deficiency, the evidence for associations with acute infections of the lower respiratory tract and with malaria is much weaker. .6,104,105 $^{2}$

Zinc is essential for the functioning of many enzymes and is thus involved in a large number of metabolic processes, including RNA and DNA synthesis. ${ }^{78,100}$ Consequently, zinc deficiency interferes with a variety of biological functions, such as gene expression, protein synthesis, skeletal growth, gonad development, appetite and immunity. Zinc plays a central role in the function of cells mediating unspecific immunity, such as neutrophils and natural killer cells, and is needed for specific immune processes, such as balancing $\mathrm{T}$ helper cell functions. ${ }^{100}$ Zinc deficiency is a major determinant for diarrhea and pneumonia, but evidence about its role in malaria and growth retardation is conflicting. ${ }^{78,106-110}$

\section{Management and control}

Foods with a high content of absorbable micronutrients are considered the best means for preventing micronutrient deficiencies. ${ }^{11-113}$ In communities where supplies of such foods are unavailable, specific preventive and curative interventions are needed. ${ }^{92,114}$

There is growing consensus on the importance of multiple micronutrient interventions in populations with a high prevalence of malnutrition..$^{112,115}$ However, synergistic and antagonistic interactions between micronutrients have to be taken into consideration during the development of appropriate formulations. ${ }^{115-125} \mathrm{~A}$ special kind of intervention is the provision of fat-based spreads (e.g., peanut butter) and "sprinkles" containing multiple micronutrients to be mixed with food. ${ }^{15}$ A principle limitation of all these interventions (except dietary diversification, of course) is their orientation toward single nutrients rather than plant ingredients (e.g., phytosterols and fibre), despite the desirability of plant ingredients for the prevention of cancer and cardiovascular diseases.

Micronutrient supplementation is usually provided through the existing health services and can be taken orally or (more rarely) by injection. Priority should be given to vulnerable populations, such as pregnant women and children. ${ }^{126}$ Supplementation is mandated in cases of a specific deficiency when other approaches are too slow. Although some micronutrients must be taken daily or weekly (e.g., iron and zinc), others can be stored in the body and need only be taken at intervals of months to years (e.g., vitamin A and iodine). ${ }^{7,127}$ However, modes of delivery, patient compliance and potential toxicity all need to be considered. ${ }^{7,15}$ Table 4 decribes the principles of management and prevention of the 4 most common isolated micronutrient deficiencies.

Diet-based strategies are probably the most promising approach for a sustainable control of micronutrient deficiencies. Increasing dietary diversification through consumption of a broad variety of foods, preferably from home gardens and small livestock production, is effective. ${ }^{15,112}$ Households should be educated and supported to increase production of dark-green leafy vegetables, yellow and orange fruits, poultry, eggs, fish and milk.

A possible future strategy to prevent micronutrient deficiencies is to breed micronutrient-rich crops, through either conventional breeding techniques or genetic modification of existing crops. So far, however, the micronutrient concentrations achieved are very low. For vitamin A, nobody knows if $\beta$-carotene from the new "golden rice" variety is bioavailable and how much rice must be consumed to meet an individual's needs, and iron concentrations in bioengineered rice are no higher than those in natural varieties such as basmati or jasmine rice. ${ }^{128}$

\section{Conclusions and outlook}

Because malnutrition has many causes, only multiple and synergistic interventions embedded in true multisectoral programs can be effective. ${ }^{129}$ A variety of actions are needed, including agricultural and micronutrient interventions and the provision of safe drinking water and sanitation, education about and support for better diets, special attention to gender issues and vulnerable groups such as pregnant women and young children, and quality health services. ${ }^{15,130}$ Nutrition education about locally available protein- and micronutrient-rich plants is particularly effective and sustainable. ${ }^{131,132}$

During the United Nations Millennium Summit in 2000, 147 heads of state adopted 8 development goals. The goal specifically about hunger is to reduce extreme poverty and hunger by the year 2015 by half relative to 1990 figures, ${ }^{133}$ but progress toward the other 7 goals (universal primary education; empowerment of women; improved maternal health; decreased child mortality; advances in the prevention and management of HIV/AIDS, malaria and other diseases; environmental protection; and global partnerships for development) would directly or indirectly contribute to major reductions of malnutrition in developing countries. 
This article has been peer reviewed.

From the Department of Tropical Hygiene and Public Health, Ruprecht-KarlsUniversity Heidelberg (Müller), and the Institute of Nutritional Sciences and Department of Pediatrics, Justus-Liebig-University Giessen (Krawinkel), Germany

Competing interests: None declared.

Contributors: Both authors contributed substantially to the study conception and design, data collection and analysis, and drafting and revision of the article. Both approved the final version to be published.

\section{References}

1. Schofield C, Ashworth A. Why have mortality rates for severe malnutrition remained so high? Bull World Health Organ 1996;74:223-9.

2. World Health Organization. World health report. Geneva: The Organization; 2002

3. Brabin BJ, Coulter JBS. Nutrition-associated disease. In: Cook GC, Zuml AI, editors. Manson's tropical diseases. London: Saunders; 2003. pp. 561-80.

4. World Health Organization, United Nations Children's Fund. Joint statement on the management of acute diarrhoea. Geneva: The Organization; 2004

5. Food and Agriculture Organization of the United Nations. Undernourishment around the world. In: The state of food insecurity in the world 2004. Rome The Organization; 2004.

6. Pinstrup-Andersen P, Burger S, Habicht JP, Peterson K. Protein-energy malnutrition. In: Jamison DT, Mosley WH, Measham AR, Bobadilla JL, editors. Disease control priorities in developing countries. 2nd ed. Oxford (UK): Oxford University Press; 1993. pp. 391-420.

7. Levin HM, Pollitt E, Galloway R, McGuire J. Micronutrient deficiency disorders. In: Jamison DT, Mosley WH, Measham AR, Bobadilla JL, editors. Disease control priorities in developing countries. 2nd ed. Oxford (UK): Oxford University Press; 1993. pp. 421-451.

8. Millward DJ, Jackson AA. Protein/energy ratios of current diets in developed and developing countries compared with a safe protein/energy ratio: implications for recommended protein and amino acid intakes. Public Health Nutr 2004;7:387-405.

9. De Onis M, Monteiro C, Akré J, Clugston G. The worldwide magnitude of protein-energy malnutrition: an overview from the WHO Global Database on Child Growth. Bull World Health Organ 1993;71:703-12.

10. Dickson R, Awasthi S, Williamson P, Demellweek C, Garner P. Effects of treatment for helminth infection on growth and cognitive performance in children: systematic review of randomized trials. BM7 2000;320:1697-701.

11. Stoltzfus RJ, Chway HM, Montresor A, Tielsch JM, Jape JK, Albonico M, et al. Low dose daily iron supplementation improves iron status and appetite but not anemia, whereas quarterly antihelminthic treatment improves growth, appetite and anemia in Zanzibari preschool children. 7 Nutr 2004;134:348-56.

12. Murray CJL, Lopez AD. Global mortality, disability, and the contribution of risk factors: Global Burden of Disease Study. Lancet 1997;349:1436-42.

13. Rice AL, Sacco L, Hyder A, Black RE. Malnutrition as an underlying cause of childhood deaths associated with infectious diseases in developing countries. Bull World Health Organ 2000;78:1207-21.

14. Black R. Micronutrient deficiency - an underlying cause for morbidity and mortality. Bull World Health Organ 2003;81:79.

15. Nemer L, Gelband H, Jha P; Commission on Macroeconomics and Health. The evidence base for interventions to reduce malnutrition in children under five and school-age children in low- and middle-income countries. $\mathrm{CMH}$ working paper no WG5:11. Geneva: World Health Organization; 2001

16. Müller O, Garenne M, Kouyaté B, Becher H. The association between protein-energy malnutrition, malaria morbidity and all-cause mortality in West African children. Trop Med Int Health 2003;8:507-11.

17. Black RE, Morris SS, Bryce J. Where and why are 10 million children dying every year? Lancet 2003;361:2226-34.

18. Chen LC, Chowdhury AKMA, Huffman SL. Anthropometric assessment of energy-protein malnutrition and subsequent risk of mortality among preschool aged children. Am 7 Clin Nutr 1980;33:1836-45.

19. Pelletier DL, Frongillo EA, Habicht JP. Epidemiologic evidence for a potentiating effect of malnutrition on child mortality. Am 7 Public Health 1993;83 1130-3.

20. Van den Broeck J, Eeckels R, Vuylsteke J. Influence of nutritional status on child mortality in rural Zaire. Lancet 1993;341:1491-5.

21. Man WD, Weber M, Palmer A, Schneider G, Wadda R, Jaffar S, et al. Nutritional status of children admitted to hospital with different diseases and its relationship to outcome in The Gambia, West Africa [published erratum appears in Trop Med Int Health 1998;3:854]. Trop Med Int Health 1998;3:678-86.

22. Fernandez ID, Himes JH, De Onis M. Prevalence of nutritional wasting in populations: building explanatory models using secondary data. Bull World Health Organ 2002;80:282-91.

23. Duncan T; Commission on Macroeconomics and Health. Health, nutrition and economic prosperity: a microeconomic perspective. $\mathrm{CMH}$ working paper no WG1: 7. Geneva: World Health Organization; 2001

24. Sachs JD, McArthur JW. The Millennium Project: a plan for meeting the Millennium Development Goals [published erratum appears in Lancet 2005 365:1138]. Lancet 2005;365:347-53 (erratum, 365:1138).

25. De Waal A, Whiteside A. New variant famine: AIDS and food crisis in southern Africa. Lancet 2003;362:1234-7.

26. Salama P, Spiegel P, Talley L, Waldman R. Lessons learned from complex emergencies over past decade. Lancet 2004;364:1801-13.

27. Young H, Borrel A, Holland D, Salama P. Public nutrition in complex emergencies. Lancet 2004;364:1899-909.

28. Kwena AM, Terlouw DJ, de Vlas SJ, Phillips-Howard PA, Hawley WA, Friedman JF, et al. Prevalence and severity of malnutrition in pre-school children in a rural area of western Kenya. Am 7 Trop Med Hyg 2003;68(4 Suppl):94-9.

29. Williams CD. Kwashiorkor: a nutritional disease of children associated with a maize diet. Lancet 1935;1151-2

30. Chen LC, Scimshaw NS. Diarrea and malnutrition: interactions, mechanisms, and interventions. New York: United Nations University Press; 1983.

31. Reilly JJ. Understanding chronic malnutrition in childhood and old age: role of energy balance research. Proc Nutr Soc 2002;61:321-7.

32. Lerner AB. On the etiology of vitiligo and gray hair. Am 7 Med 1971;51:141-7.

33. Bhan MK, Bhandari N, Bahl R. Management of the severely malnourished child: perspective from developing countries. BM7 2003;326:146-51.

34. Hendrickse RG. Of sick turkeys, kwashiorkor, malaria, perinatal mortality, heroin addicts and food poisoning: research on the influence of aflatoxins on child health in the tropics. Ann Trop Med Parasitol 1997;91:787-93.

35. Reid M, Badaloo A, Forrester T, Morlese JF, Heird WC, Jahoor F. The acute phase protein response to infection in edematous and non-edematous proteinenergy malnutrition. Am 7 Clin Nutr 2002;76:1409-15.

36. Ramdath DD, Golden MH. Elevated glutathione S-transferase activity in erythrocytes from malnourished children. Eur 7 Clin Nutr 1993;47:658-65.

37. Becker K, Leichsenring M, Gana L, Bremer HJ, Schirmer RH. Glutathione and associated antioxidant systems in protein energy malnutrition: results of a study in Nigeria. Free Radic Biol Med 1995;18:257-63.

38. Lenhartz H, Ndasi R, Anninos A, Botticher D, Mayatepek E, Tetanye E, et al. The clinical manifestation of the kwashiorkor syndrome is related to increased lipid peroxidation. 7 Pediatr 1998;132:879-81.

39. Golden MHN. Oedematous malnutrition. Br Med Bull 1998;54:433-44

40. Manary MJ, Leewenburgh C, Heinecke JW. Increased oxidative stress in kwashiorkor. 7 Pediatr 2000;137:421-4.

41. Jackson AA. Glutathione in kwashiorkor. Am 7 Clin Nutr 2002;76:495-6.

42. Badaloo A, Reid M, Forrester T, Heird WC, Jahoor F. Cysteine supplementation improves the erythrocyte glutathione synthesis rate in children with severe edematous malnutrition. Am 7 Clin Nutr 2002;76:646-52.

43. Krawinkel M. Kwashiorkor is still not fully understood. Bull World Health Organ 2003;81:910-1.

44. Ciliberto H, Ciliberto M, Briend A, Ashorn P, Bier D, Manary M. Antioxidant supplementation for the prevention of kwashiorkor in Malawian children: randomised, double blind, placebo controlled trial. BM7 2005;330:1109.

45. Fuchs GJ. Antioxidants for children with kwashiorkor. BMF 2005;330:1095-6

46. Rossi MA, Zucoloto S. Ultrastructural changes in nutritional cardiomyopathy of protein-calorie malnourished rats. Br 7 Exp Pathol 1982;63:242-53.

47. Gracey M. Nutritional effects and management of diarrhoea in infancy. Acta Paediatr Suppl 1999;88:110-26.

48. Alam NH, Hamadani JD, Dewan N, Fuchs GJ. Efficacy and safety of a modified oral rehydration solution ( $\mathrm{ReSoMaL})$ in the treatment of severely malnourished children with watery diarrhea. F Pediatr 2003;143:614-9.

49. Van der Hoek W, Feenstra SG, Konradsen F. Availability of irrigation water for domestic use in Pakistan: its impact on prevalence of diarrhoea and nutritional status of children. 7 Health Popul Nutr 2002;20:77-84.

50. Manary MJ, Brewster DR. Potassium supplementation in kwashiorkor. 7 Pediatr Gastroenterol Nutr 1997;24:194-201.

51. Brown KH. Appropriate diets for the rehabilitation of malnourished children in the community setting. Acta Paediatr Scand Suppl 1991;374:151-9.

52. Khanum S, Ashworth A, Huttly SR. Controlled trial of three approaches to the treatment of severe malnutrition. Lancet 1994;344:1728-32.

53. Gernaat HB, Dechering WH, Voorhoeve HW. Mortality in severe proteinenergy malnutrition at Nchelenge, Zambia. 7 Trop Pediatr 1998;44:211-7.

54. Ahmed T, Ali M, Ullah MM, Choudhury IA, Haque ME, Salam MA, et al Mortality in severely malnourished children with diarrhoea and use of a standardised management protocol. Lancet 1999;353:1919-22.

55. Ambrus JL Sr, Ambrus JL Jr. Nutrition and infectious diseases in developing countries and problems of acquired immunodeficiency syndrome. Exp Biol Med (Maywood) 2004;229:464-72.

56. Heikens GT. Rebabilitation of sick malnourished children - environments, requirements, prognosis and feasibility. Amsterdam: Rozenberg Publications; 2003.

57. Beaufrere B, Bresson JL, Briend A, Ghisolfi J, Goulet O, Navarro J, et al. [Protein and energy needs of the infant with severe malnutrition: application in a hospital environment for the treatment of malnutrition caused by deficient intake] [review]. Arch Pediatr 1998;5:763-71.

58. World Health Organization. Management of severe malnutrition: a manual for 
physicians and other senior health workers. Geneva: The Organization; 1999.

59. World Health Organization. Management of the child with a serious infection or severe malnutrition. Guidelines for care at the first-referral level in developing countries. Geneva: The Organization; 2000.

60. Ashworth A, Chopra M, McCoy D, Sanders D, Jackson D, Karaolis N, et al. WHO guidelines for management of severe malnutrition in rural South African hospitals: effect on case fatality and the influence of operational factors. Lancet 2004;363:1110-5.

61. World Health Organization. Informal consultation to review current literature on severe malnutrition. Geneva: The Organization. In press. Highlights available: www.who.int/hac/about/donorinfo/13September04_MondayHighlights.pdf (accessed 2005 July 6).

62. World Health Organization, United Nations Children's Fund. Expert consultation on oral rebydration salts (ORS) formulation. Report from a meeting of experts jointly organized by UNICEF and WHO; 2001 Jul 18; New York.

63. World Health Organization. World health report. Geneva: WHO; 2004.

64. Makonnen B, Venter A, Joubert G. A randomized controlled study of the impact of dietary zinc supplementation in the management of children with protein-energy malnutrition in Lesotho. II: Special investigations. 7 Trop Pediatr 2003; 49:353-60.

65. Golden $\mathrm{MH}$, Briend A. Treatment of malnutrition in refugee camps. Lancet 1993;342:360.

66. Ibekwe VE, Ashworth A. Management of protein-energy malnutrition in Nigeria: an evaluation of the regimen at the Kersey Nutrition Rehabilitation Centre, Nigeria. Trans R Soc Trop Med Hyg 1994;88:594-5.

67. Thapar N, Sanderson I. Diarrhoea in children: an interface between developing and developed countries [review]. Lancet 2004;363:641-53.

68. Pyle DF. Growth charts don't cure malnutrition. World Educ Rep 1986;(25): $15-7$.

69. Sauerborn R, Nougtara A, Sorgho G, Bidiga J, Diesfeld HJ. Assessment of MCH services in the district of Solenzo, Burkina Faso. III. Effectiveness of $\mathrm{MCH}$ services in detecting of and caring for mothers and children at risk. $\mathcal{F}$ Trop Pediatr 1989;35(1 Suppl):14-7.

70. Melville B, Fidler T, Mehan D, Bernard E, Mullings J. Growth monitoring: the role of community health volunteers. Public Health 1995;109:111-6.

71. Feachem RG, Koblinsky MA. Interventions for the control of diarrheal diseases among young children: promotion of breast-feeding. Bull World Health Organ 1984;62:271-91.

72. Marek T, Diallo I, Ndiaye B, Rakotosalama J. Successful contracting of prevention services: fighting malnutrition in Senegal and Madagascar. Health Policy Plan 1999;14:382-9.

73. Victora CG, Kirkwood BR, Ashworth A, Black RE, Rogers S, Sazawal S, et al Potential interventions for the prevention of childhood pneumonia in developing countries: improving nutrition. Am 7 Clin Nutr 1999;70:309-20.

74. Shah D, Gupta P. Management of severe malnutrition: facilitating learning [letter]. Lancet 2003;361:2088.

75. Armstrong Schellenberg JR, Adam T, Mshinda H, Masanja H, Kabadi G, Mukasa $\mathrm{O}$, et al. Effectiveness and cost of facility-based Integrated Management of Childhood Illness (IMCI) in Tanzania. Lancet 2004;364:1583-94.

76. El Arifeen S, Blum LS, Hoque DME, Chowdhury EK, Khan R, Black RE, et al. Integrated Management of Childhood Illness (IMCI) in Bangladesh: early findings from a cluster-randomised study. Lancet 2004;364:1595-602.

77. Diaz JR, de las Cagigas A, Rodriguez R. Micronutrient deficiencies in developing and affluent countries [review]. Eur 7 Clin Nutr 2003;57:S70-2.

78. Shankar A. Nutritional modulation of malaria morbidity and mortality [review]. 7 Infect Dis 2000;182(Suppl 1):S37-53.

79. De Benoist B, Clugston G. Eliminating iron deficiency disorders [editorial]. Bull World Health Organ 2002;80:341.

80. Hetzel BS. Eliminating iodine deficiency disorders - the role of the International Council in the global partnership. Bull World Health Organ 2002;80. 410-17.

81. Black MM. Micronutrient deficiencies and cognitive functioning [review]. 7 Nutr 2003;133(11 Suppl 2):3927S-31S.

82. Stoltzfus RJ, Dreyfuss ML. Guidelines for the use of iron supplements to prevent and treat iron deficiency anemia. Washington: International Life Sciences Institute Press; 1998.

83. Fleming AF, de Silva PS. Haematological diseases in the tropics. In: Cook GC, Zumla AI, editors. Manson's tropical diseases. London: Saunders; 2003. pp. 169-244.

84. Krawinkel MB, Bethge M, el Karib AO, Ahmet HM, Mirghani OA. Maternal ferritin values and foetal iron stores. Acta Paediatr Scand 1990;79:467.

85. Hesham MS, Edariah AB, Norhayati M. Intestinal parasitic infections and micronutrient deficiency: a review. Med 7 Malaysia 2004;59:284-93.

86. Zimmermann MB, Chaouki N, Hurrell RF. Iron deficiency due to consumption of a habitual diet low in bioavailable iron: a longitudinal cohort study in Moroccan children. Am 7 Clin Nutr 2005;81:115-21.

87. Cook JD, Skikne BS, Baynes RD. Iron deficiency: the global perspective. Adv Exp Med Biol 1994;356:219-28.

88. Sikosana PL, Bhebhe S, Katuli S. A prevalence survey of iron deficiency and iron deficiency anaemia in pregnant and lactating women, adult males and pre-school children in Zimbabwe. Cent Afr 7 Med 1998;44:297-305.
89. Yip R, Ramakrishnan U. Experiences and challenges in developing countries. 7 Nutr 2002;132(4 Suppl):827S-30S.

90. Shali T, Singh C, Goindi G. Prevalence of anemia amongst pregnant mothers and children in Delhi. Indian 7 Pediatr 2004;71:946.

91. World Health Organization. Global prevalence of vitamin A deficiency. Micronutrient Deficiency Information System (MDIS) Working Paper No. 2. Document WHO/NUT/95.3. Geneva: The Organization; 1995.

92. Adamson P; for UNICEF and Micronutrient Initiative. Vitamin and mineral deficiency: a global progress report. New York: United Nations Children's Fund; 2003.

93. McGavin DDM. Ophthalmology in the tropics and subtropics. In: Cook GC, Zumla AI, editors. Manson's tropical diseases. London: Saunders; 2003. pp. 301-62. 94. Glasziou PP, Mackerras DEM. Vitamin A supplementation in infectious diseases: a meta-analysis. BM7 1993;306:366-70.

95. Fawzi WW, Chalmers TC, Herrera MG, Mosteller F. Vitamin A supplementation and child mortality: a meta-analysis. FAMA 1993;269:898-903.

96. Ghana VAST Study Team. Vitamin A supplementation in northern Ghana: effects on clinic attendances, hospital admissions, and child mortality [published erratum appears in Lancet 1993;342(8865):250]. Lancet 1993;342:7-12.

97. Vijayaraghavan K. Vitamin A deficiency. Lancet 2000;356(Suppl):s41.

98. Humphrey JH, Rice AL. Vievpoint: Vitamin A supplementation of young infants. Lancet 2000;356:422-4.

99. Prasad AS. Zinc deficiency has been known for 40 years but ignored by global health organisations. $B M \dot{7} 2003 ; 326: 409-10$

100. Shankar AH, Prasad AS. Zinc and immune function: the biological basis of altered resistance to infection. Am 7 Clin Nutr 1998;68(2 Suppl):447S-63S.

101. Black RE. Therapeutic and preventive effects of zinc on serious childhood infectious diseases in developing countries. Am 7 Clin Nutr 1998;68(2 Suppl): 476S-9S.

102. Aggett PJ. Severe zinc deficiency. In: Mills CF, editors. Zinc in buman biology. New York: Springer-Verlag; 1989. p. 259-79.

103. Semba RD. The role of vitamin A and related retinoids in immune function [review]. Nutr Rev 1998;56(1 Pt 2):S38-48.

104. Barreto ML, Santos LMP, Assis AMO, Araujo MPN, Farenzena GG, Santos $\mathrm{PAB}$, et al. Effect of vitamin A supplementation on diarrhoea and acute lower-respiratory-tract infections in young children in Brazil. Lancet 1994; 344:228-31.

105. Müller O, Jahn A, von Braun J. Micronutrient supplementation for malaria control - hype or hope? [editorial]. Trop Med Int Health 2002;7:1-3.

106. Sazawal S, Black RE, Bhan MK, Bhandari N, Sinha A, Jalla S. Zinc supplementation in young children with acute diarrhea in India. N Engl 7 Med 1995 333:839-44.

107. Brown KH, Peerson JM, Allen LH. Effect of zinc supplementation on children's growth: a meta-analysis of intervention trials. Bibl Nutr Dieta 1998;54:76-83.

108. Bhutta ZA, Black RE, Brown KH, Gardner JM, Gore S, Hidayat A, et al; for Zinc Investigators' Collaborative Group. Prevention of diarrhea and pneumonia by zinc supplementation in children in developing countries: pooled analysis of randomized controlled trials. 7 Pediatr 1999;135:689-97.

109. Müller O, Becher H, [Baltussen] van Zweeden A, Ye Y, Diallo DA, Konate AT, et al. Effect of zinc supplementation on malaria and other causes of morbidity in west African children: randomized double blind placebo controlled trial. $B M 7$ 2001;322:1567-72

110. Müller O, Garenne M, Reitmaier P, [Baltussen] van Zweeden A, Kouyate B, Becher H. Effect of zinc supplementation on growth in West African children: a randomized double-blind placebo-controlled trial in rural Burkina Faso. Int 7 Epidemiol 2003;32:1098-102.

111. Gibson RS, Yeudall F, Drost N, Mtitimuni B, Cullinan T. Dietary interventions to prevent zinc deficiency. Am 7 Clin Nutr 1998;68(2 Suppl):484S-7S.

112. Tontisirin K, Nantel G, Bhattacharjee L. Food-based strategies to meet the challenges of micronutrient malnutrition in the developing world. Proc Nutr Soc 2002;61:243-50.

113. International Zinc Nutrition Consultative Group. Assessment of the risk of zinc deficiency in populations and options for its control. Food Nutr Bull 2004, 25:S91-204

114. Holmes W, Toole M. Micronutrient supplements in pregnant Nepalese women. Lancet 2005;365:916-7.

115. Shrimpton R, Gross R, Darnton-Hill I, Young M. Zinc deficiency: What are the most appropriate interventions? BM7 2005;330:347-9.

116. Baly DL, Golub MS, Gershwin ME, Hurley LS. Studies of marginal zinc deprivation in rhesus monkeys. 3. Effects of vitamin A metabolism. Am 7 Clin Nutr 1984;40:199-207.

117. Bloem MW, Wedel M, van Agtmaal EJ, Speek AJ, Saowakontha S, Schreurs WH. Vitamin A intervention: short-term effects of a single, oral, massive dose on iron metabolism. Am 7 Clin Nutr 1990;51:76-9.

118. Allen LH. Zinc and micronutrient supplements for children [review]. Am 7 Clin Nutr 1998;68(2 Suppl):495S-8S.

119. Christian P, West KP Jr. Interactions between zinc and vitamin A: an update. Am 7 Clin Nutr 1998;68(2 Suppl):435S-41S.

120. Gibson RS. Zinc supplementation for infants. Lancet 2000;355:2008-9.

121. Rahman MM, Vermund SH, Wahed MA, Fuchs GJ, Baqui AH, Alvarez JO. Simultaneous zinc and vitamin A supplementation in Bangladeshi children: randomised double blind controlled trial. BMF 2001;323:314-8. 
122. Zimmermann MB, Zeder C, Chaouki N, Torresani T, Saad A, Hurrell RF. Addition of microencapsulated iron to iodized salt improves the efficacy of iodine in goitrous, iron-deficient children: a randomized, double-blind, controlled trial. Eur 7 Endocrinol 2002;147:747-53.

123. Zimmermann MB, Zeder C, Chaouki N, Saad A, Torresani T, Hurrell RF. Dual fortification of salt with iodine and microencapsulated iron: a randomized, double-blind, controlled trial in Moroccan schoolchildren. Am 7 Clin Nutr 2003;77:425-32.

124. Zimmermann MB, Wegmueller R, Zeder C, Chaouki N, Biebinger R, Hurrell $\mathrm{RF}$, et al. Triple fortification of salt with microcapsules of iodine, iron, and vitamin A. Am 7 Clin Nutr 2004;80:1283-90.

125. Hurrell RF, Lynch S, Bothwell T, Cori H, Glahn R, Hertrampf E, et al. Enhancing the absorption of fortification iron. A SUSTAIN Task Force report [review]. Int 7 Vitam Nutr Res 2004;74:387-401.

126. Osrin D, Vaidya A, Shrestha Y, Baniya RB, Manandahar DS, Adhikari RK, et al. Effects of antenatal multiple micronutrient supplementation on birthweight and gestational duration in Nepal: double-blind, randomised controlled trial. Lancet 2005;365:955-62.

127. Siddiqui IA, Rahman MA, Jaleel A. Efficacy of daily vs. weekly supplementation of iron in schoolchildren with low iron status. 7 Trop Pediatr 2004;50:276-8.

128. Gregorio GB. Progress in breeding for trace minerals in staple crops. $7 \mathrm{Nutr}$ 2002;132:500S-2S.
129. Bhargava A; Commission on Macroeconomics and Health. Nutrition, bealth, and economic development: some policy priorities. $\mathrm{CMH}$ working paper no. Geneva: World Health Organization; 2001.

130. Victora CG, Hanson K, Bryce J, Vaughan P. Achieving universal coverage with health interventions. Lancet 2004;364:1541-8

131. Penny ME, Creed-Kanashiro HM, Robert RC, Narro MR, Caulfield LE, Black RE. Effectiveness of an educational intervention delivered through the health services to improve nutrition in young children: a cluster-randomised controlled trial. Lancet 2005;365:1863-72.

132. Dewey KG. Infant nutrition in developing countries: What works? Lancet 2005;365:1832-4.

133. UN Millennium Project Task Force on Hunger. Halving hunger: it can be done. Sterling (VA): Earthscan; 2005. Summary available: www.unmillenniump roject.org/documents/htf-SumVers_final.pdf (accessed 2005 June 28).

Correspondence to: Dr. Olaf Müller, Department of Tropical Hygiene and Public Health, INF 324, 69120 Heidelberg, Ruprecht-Karls-University Heidelberg, Germany; olaf.mueller@urz.uni-heidelberg.de 